\title{
Direct Potentiometric Determination of Penicill- amine in Real Samples by Using Copper ISE
}

\author{
Tina Vukušić, ${ }^{1}$ Ante Prkić, ${ }^{1,}{ }^{*}$ Josipa Giljanović, ${ }^{1}$ Vesna Sokol, ${ }^{2}$ Perica Bošković ${ }^{2}$
}

\footnotetext{
1 Department of Analytical Chemistry, Faculty of Chemistry and Technology, Teslina 10/V, 21000 Split, Croatia

2 Department of Physical Chemistry, Faculty of Chemistry and Technology, Teslina 10/V, 21000 Split, Croatia

* Corresponding author's e-mail address: prkic@ktf-split.hr
}

RECEIVED: March 13, 2015 * REVISED: September 18, 2015 * ACCEPTED: September 23, 2015

Abstract: Direct potentiometric method for determination of penicillamine in pharmaceuticals by using commercial copper ISE is described. Proposed method is very inexpensive, simple and reasonably fast method for determination of Pen in acetic buffer, $\mathrm{pH}=4$ without pretreatment of pharmaceuticals. Determination is based on the reaction between Pen and $\mathrm{Cu}^{2+}$ from electrode membrane. Described method has linear response range for Pen from $2 \times 10^{-6}$ to $1 \times 10^{-2} \mathrm{~mol} \mathrm{~L}^{-1}$ with limit of detection of $1.1 \times 10^{-6} \mathrm{~mol} \mathrm{~L}^{-1}$. Found concentrations of Pen are in very good agreement with declared ones with standard deviation values in range $4.00-4.50 \%$.

Keywords: penicillamine, potentiometric, determination, ion-selective electrode.

\section{INTRODUCTION}

$\mathbf{P}$ ENICILLAMINE (Pen) is amino acid used in the body for chelating copper ions. Pen is taken as pharmaceutical (e.g. Metalcaptase ${ }^{\circledast}$ ) and it is useful in Wilson disease treatment. Wilson disease is characterized by accumulation of copper in tissue of liver, brain and eyes (edge of iris) as well as potential neuropsychiatric symptoms (tremor, ataxia, dystonia etc.). Pen creates simple stoichiometry complex (1:1) with copper(II) ions. Complex created in that way makes possible secretion of copper excess in urine from body. Pen is used for cystinuria treatment too. Cystinuria is characterized by creation of cysteine stones or cystine when two molecules of cysteine create disulfide bond. Cysteine stones are sparingly soluble and their secretion from body is stiff. Pen makes disulfide bonds with cysteine that yields a disulfide compound significantly soluble of cysteine and makes secretion easy.

There are few recent papers in literature that describe direct potentiometric determinations of thiols/Pen. ${ }^{[1-8]}$ Other proposed methods are based on different techniques, such as voltammetry, ${ }^{[9-13]}$ spectrophotometry ${ }^{[14-17]}$ and chromatographic techniques. ${ }^{[18]}$
Due the high Pen medical value, it is very important to develop a new method, especially direct one, because it could be found a few methods dedicated for Pen determination.

We are proposing a method suitable for direct determination of Pen in wide concentration range without pretreatment of pharmaceuticals. Proposed method is very inexpensive, simple and fast. Using proposed Cu ISE as sensor for determination of Pen in pharmaceuticals makes proposed method a very robust one.

\section{EXPERIMENTAL}

\section{Reagents and Chemicals}

All needed solutions were prepared by solving certain amount of solid chemicals in suprapure water. Suprapure water (declared conductivity $0.04 \mu \mathrm{S} \mathrm{cm}^{-1}$ ) was prepared by Millipore Simplicity (Millipore, USA).

Following chemicals were used: Sodium nitrate, $\mathrm{NaNO}_{3}$, p.a., Sodium acetate, $\mathrm{CH}_{3} \mathrm{COONa}$, p.a., Acetic acid, $\mathrm{CH}_{3} \mathrm{COOH}$, p.a., Copper(II) nitrate, $\mathrm{Cu}\left(\mathrm{NO}_{3}\right) \times 3 \mathrm{H}_{2} \mathrm{O}$, p.a., Kemika (Croatia) and DL-penicillamine, $\mathrm{C}_{5} \mathrm{H}_{11} \mathrm{NO}_{2} \mathrm{~S}$, p.a., Alfa Aesar (Germany). All used solutions were prepared by 


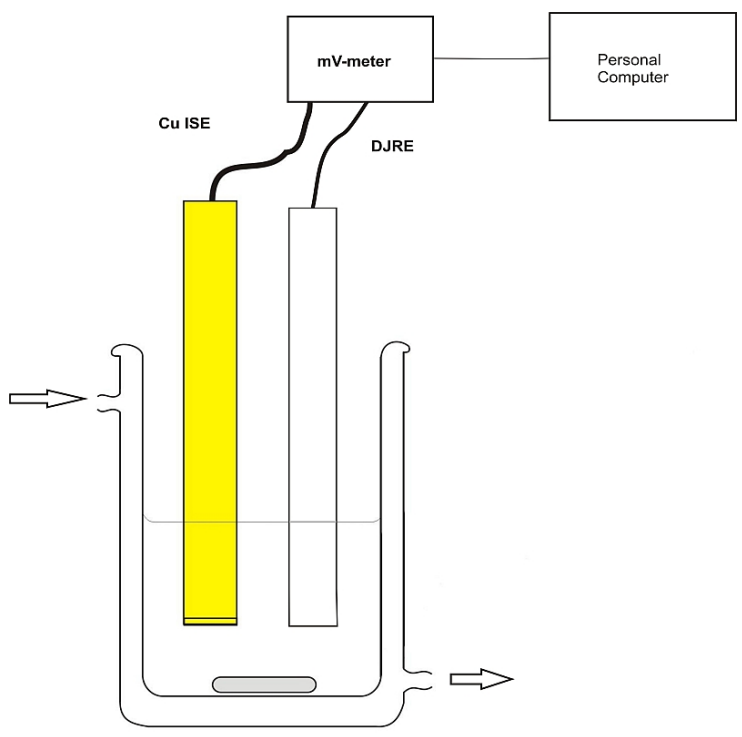

Figure 1. Potenciometric system used in experimental work.

dissolving a needed mass of substance in acetic buffer $\mathrm{pH}=$ 4. Acetic buffer was $0.1 \mathrm{M}$. Sodium nitrate was used for adjusting ionic strength at $0.5 \mathrm{M}$.

\section{Apparatus}

The indicator electrode was an Orion 94-29A copper ion-selective electrode (CU-ISE) and as reference electrode was used an Orion 90-02 double junction reference electrode (DJRE) made by Orion, USA. Potentiometric data were recorded at thermostated vessel (temperature was kept in range $25 \pm 0.02{ }^{\circ} \mathrm{C}$ ) with a millivoltmeter (SevenExcellence, Mettler-Toledo, Switzerland-USA) coupled to a personal computer with USB cable and data were recorded by using LabX direct pH 3.3 software (Mettler-Toledo, SwitzerlandUSA) (Figure 1). The uncertainty in potential measurements was $\pm 0.0001 \mathrm{~V}$.

\section{RESULTS AND DISCUSSION}

"Classic" or "batch" potentiometric determination of both $\mathrm{Cu}^{2+}$ and Pen has been determined by using previously mentioned CU-ISE. CU-ISE has been tested for response to copper concentration in acetic buffer $\mathrm{pH}=4$ and ionic strength $0.5 \mathrm{M}$. Concentration change of $\mathrm{Cu}^{2+}$ was performed by standard dilution method. During measurement, solution was stirred and kept at constant temperature as mentioned above in Apparatus section. All measurements were made repeatedly for five times both for $\mathrm{Cu}^{2+}$ and Pen. Results are shown in Figure 2.

Points on the graph represent experimental data and straight line was calculated by using method of linear regression. As shown, copper electrode, linearly follows changing of $\mathrm{Cu}^{2+}$ concentration in wide concentration

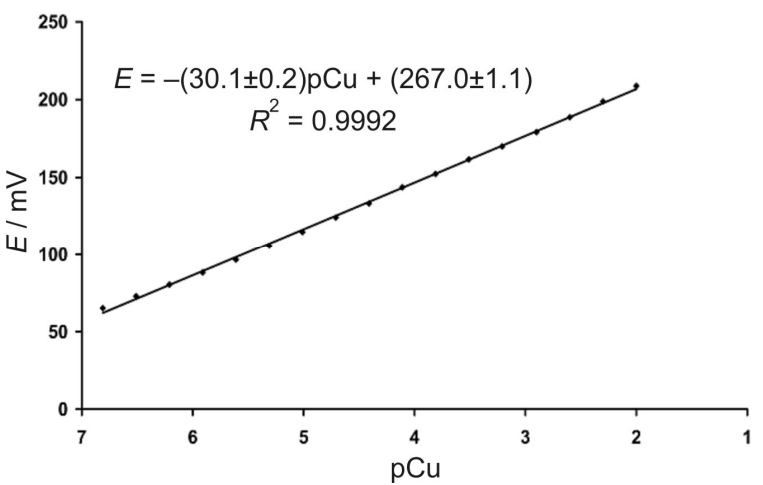

Figure 2. Response of copper ISE to $\mathrm{Cu}^{2+}$ ions in acetic buffer $\mathrm{pH}=4$.

range. Stable potential was reached in a few seconds. Potential change of $30.1 \mathrm{mV}$ per decade of copper ions concentration change was recorded, with correlation coefficient of 0.9992, which is in good agreement with theoretical Nerstian slope for divalent cations. Copper ISE linearly follows change of $\mathrm{Cu}^{2+}$ concentration with linear response in the concentration range of $\mathrm{Cu}^{2+}=1.6 \times 10^{-7}-$ $1 \times 10^{-1} \mathrm{~mol} \mathrm{~L}^{-1}$ in acetic buffer, $\mathrm{pH}=4$. Response of copper ISE to Pen was based on reaction of sulphur in thiol's group of Pen with $\mathrm{Cu}^{2+}$ from copper(II) sulfide from electrode membrane by forming complex at membrane surface described by Radic \& Dobcnik. ${ }^{[19]}$

The limit of detection (LOD) and the limit of quantification (LOQ) were calculated by using next formulae:

$$
\begin{aligned}
& \operatorname{LOD}=\frac{3 \sigma}{s} \quad \mathrm{LOQ}=\frac{10 \sigma}{s} \\
& \sigma-\text { standard deviation } \\
& s-\text { slope of curve }
\end{aligned}
$$

The same method for testing response of copper ISE to Pen as to copper ions was performed. Results are shown in Figure 3.

Points on the graph represent experimental data and straight line was calculated by using method of linear regression. It can be seen that copper ISE shows linear dependence with changing of Pen concentration in the concentration range between $1.2 \times 10^{-6}$ and $1 \times 10^{-2} \mathrm{~mol} \mathrm{~L}^{-1}$, with a detection limit $1.1 \times 10^{-6} \mathrm{~mol} \mathrm{~L}^{-1}$. Stable potential was reached in about 15 seconds. Potential change of $39.1 \mathrm{mV}$, for decade concentration change of Pen, with correlation coefficient of 0.9990 was recorded in acetic buffer, $\mathrm{pH}=4$. Recorded potential change is higher than it was expected since Pen creates a simple stoichiometry complex with copper(II) ions and it was reasonable to expect potential change of around $30 \mathrm{mV}$. It is important to stress out that similar cases were reported ${ }^{[5,7]}$ but authors did not offer an 


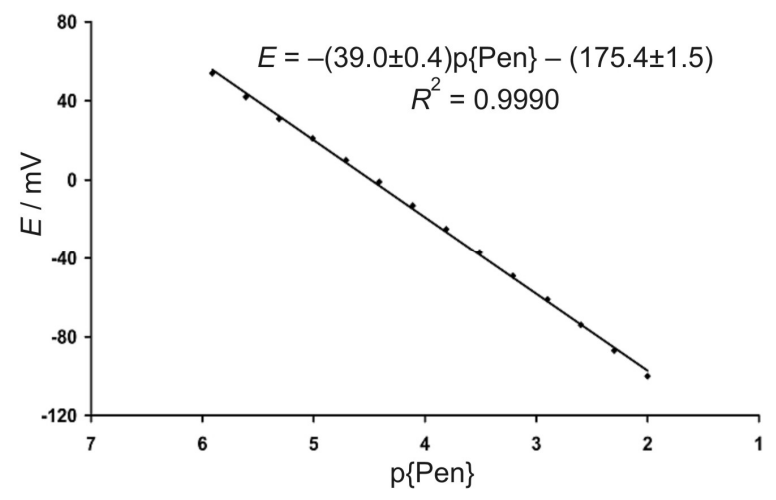

Figure 3. Response of copper ISE to Pen in acetic buffer $\mathrm{pH}=4$.

explanation. This phenomenon will be the aim of our further investigation. In previous works with similar used method $[1,2,20]$ linear response range of two concentration decade was recorded which is significantly narrower than for proposed method, almost four magnitudes of order. Because the detection limit for two methods ${ }^{[1,20]}$ was not presented, it is reasonable to assume that they are the same magnitude of order like proposed method or higher. The third method ${ }^{[2]}$ has lower detection limit $\left(9 \times 10^{-8} \mathrm{M}\right.$ versus $1.1 \times 10^{-6} \mathrm{M}$ ) that could be the result of higher reaction constant for redox (iodate ions with Pen) than complexometric (copper ions with Pen) reactions. Proposed method in comparison of earlier proposed methods is simpler since it is based on direct reaction, faster (lasts for a time needed for the potential to be stabilized) and cheaper (due to the using fewer and cheap chemicals).

Described potentiometric determination of Pen was used for measuring concentration of Pen in tested pharmaceuticals (Table 1). In experiment was used pharmaceutical with Pen, Metalcaptase ${ }^{\circledR} 150 \mathrm{mg}$, Heyl (Germany). Pharmaceuticals' solutions were prepared by dissolving one pile in appropriate volume of acetic buffer, $\mathrm{pH}=4$, and diluted with the same buffer in a $100.0 \mathrm{~mL}$ calibrated flask. In the second experiment five piles were taken, smashed in the ceramic mortar, mixed, taken $1.0000 \mathrm{~g}$ of powder and diluted in acetic buffer $\mathrm{pH}=4$, Table 1 . it can be seen a good agreement between measured and expected values with recorded recovery 99.5-100.7\%.

Table 1. Determination of Pen in real samples

\begin{tabular}{cccc}
\hline & Labeled, mg & $\begin{array}{c}\text { Found } \pm \text { SD (\%) } \\
(n=5)\end{array}$ & $\begin{array}{c}\text { Recovery } \\
(\%)\end{array}$ \\
\cline { 2 - 4 } Metalcaptase $^{\circledR}$ & $\begin{array}{c}150 \text { (one pile) } \\
565 \text { (five piles - } \\
\text { smashed, value has } \\
\text { been calculated) }\end{array}$ & $149.2 \pm 4.0$ & 99.5 \\
\hline
\end{tabular}

Table 2. Recovery studies by adding standard

\begin{tabular}{cccc}
\hline Labelled/Taken, mg & Added, mg & $\begin{array}{c}\text { Found } \pm \text { SD }(\%) \\
(n=5)\end{array}$ & $\begin{array}{c}\text { Recovery } \\
(\%)\end{array}$ \\
\hline \multirow{3}{*}{$150 / 0.9$} & 1.5 & $2.4 \pm 5.0$ & 101.7 \\
& 5 & $3.8 \pm 6.5$ & 97.7 \\
& 7.5 & $8.5 \pm 4.2$ & 100.8 \\
& 10 & $10.9 \pm 4.5$ & 100.0 \\
\hline
\end{tabular}

We performed recovery studies by adding the standard of Pen to the sample solution. Equation used for calculating Pen concentrations in tested samples was: $E=K-S \log$ $c\left(\right.$ Pen), $R^{2}=0.9990$. The data are summarized in Table 2 .

In Table 2 it can be seen that proposed method is very suitable for direct potentiometric determination of Pen.

\section{CONCLUSIONS}

Copper ion-selective electrode is an acceptable sensor in direct potentiometric determination of Pen in acetic buffer, $\mathrm{pH}=4$, without needing to use pharmaceuticals pretreatment in concentration range $c($ Pen $)=1.2 \times 10^{-6}-1 \times 10^{-2} \mathrm{~mol}$ $\mathrm{L}^{-1}$, with potential change of $39.1 \mathrm{mV}$ per decade of Pen concentration. At experimental conditions Pen forms very stable complex in reaction with $\mathrm{Cu}^{2+}$ from the surface of membrane and generate potential change. Found values of tested pharmaceuticals are in very good agreement with declared values.

Acknowledgment. The authors are grateful to Zoran Čekić, MD and Ivana Prkić, MD for providing useful data about using penicillamine as cure.

\section{REFERENCES}

[1] A. Martinovic, Nj. Radic, Anal. Lett. 2007, 40, 2851.

[2] A. Martinovic, Nj. Radic, Acta Chim. Slov. 2009, 56, 503.

[3] M. Kolar, D. Dobcnik, Pharmazie 2003, 58, 25.

[4] J. Giljanović, A. Prkić, Molecules 2010, 15, 100.

[5] A. Prkić, J. Giljanović, M. Bralić, Int. J. Electrochem. Soc. 2011, 6, 5388.

[6] D. Dobcnik, D, M. Kolar, J. Komljenovic, N. Radic, Fresen. J. Anal. Chem. 1999, 365, 314.

[7] M. Kolar, D. Dobcnik, N. Radic, Mikrochim. Acta 2002, 138, 23.

[8] M. Kolar, D. Dobcnik, N. Radic, Pharmazie 2000, 55, 913.

[9] J. B. Raoof, R. Ojani, F. Chekin, M. Jahanshahi, S. Rashid-Nadim, Electroanal. 2009, 21, 2674. 
[10] J. B. Raoof, R. Ojani, M. Amiri-Aref, F. Chekin, J. Appl. Electrochem. 2010, 40, 1357.

[11] M. Mazloum-Ardakani, M. A. Sheikh-Mohseni, B. F. Mirjalili, Electroanal. 2013, 25, 2021.

[12] J. B. Raoof, R. Ojani, M. Amiri-Aref, F. Chekin, Russ. J. Electrochem. 2012, 48, 450.

[13] A. Ghaffarinejad, F. Hashemi, Z. Nodehi, R. Salahandish, Bioelectrochemistry 2014, 99, 53.

[14] B. Franciszek, M. Galkowska, Chem. Anal. (Warsaw) 2006, 51, 623.

[15] H. J. Vieira, O. Fatibello-Filho, Quim. Nova 2005, 28, 797.
[16] A. Martinovic-Bevanda, Nj. Radic, Anal. Sci. 2013, 29, 669.

[17] J. Giljanović, M. Brkljača, A. Prkić, Molecules 2011, 16, 7224.

[18] M. A. Saracino, C. Cannistraci, F. Bugamelli, E. Morganti, I. Neri, R. Balestri, A. Patrizi, M. A. Raggi, Talanta 2013, 103, 355.

[19] Nj. Radic, and D. Dobcnik, Surf. Rev. Lett. 2000, 8, 361.

[20] Nj. Radić, J. Komljenović, and D. Dobčnik, Croat. Chem. Acta 2000, 73, 263. 